\title{
Effectiveness of Malaysian Property Maintenance and Management Outsourcing
}

\author{
Lee Chin Sheng ${ }^{1}$ and Zarita Ahmad Baharum ${ }^{2}$ \\ ${ }^{1}$ School of the Built Environment, Heriot-Watt University, Edinburgh Scotland \\ ${ }^{2}$ Department of Estate Management, Faculty of Architecture, Planning and Surveying, Universiti Teknologi Mara (UiTM), \\ Selangor, Malaysia \\ *1cs_lee86@yahoo.com
}

\begin{abstract}
The effectiveness of outsourcing implementations and practices in the property maintenance and management (PMM) sector in Malaysia needs to be investigated and service chasm to be ascertained for the improvement and development of the industry. A survey was conducted among outsourcing clients and outsourcing service providers to determine the effectiveness of current services provision. A quantitative method by means of survey questionnaire is used in investigating the PMM outsourcing effectiveness and implementations in practice. Chasm analysis which stemmed from the mean result derived from the study depicts the ineffectiveness of the current PMM services outsourcing implementations and practices. Outsourcing effectiveness criteria of quality and risk and liabilities appeared to be at the top of the list on mean difference analysis between outsourcing clients and outsourcing service providers. Outsourcing service provider should be aware of this perception gap for their subsequent mitigation and improvement planning. Priority should be given to those effectiveness criteria with the largest mean difference gap from the analysis. The paper provides empirical data for PMM services outsourcing practitioner in Malaysia for their insight on the current services performance and effectiveness level. The result will aid service providers in strategizing future direction and improvement planning of respective firm and enhance the services delivery to outsourcing client.
\end{abstract}

Keywords: outsourcing, outsourcing effectiveness, outsourcing implementation, property maintenance, property management, Malaysia

\subsection{INTRODUCTION}

Outsourcing is the use of external providers, multiple or single, for peripheral support services (Jan et al., 2002). It is a tool and preferred option by the organisations used to maintain competitiveness in the present changing environment. Thus, with the current competitive business environment coupled with rapid advancing of technology, the expectations of clients were not always met as they become more sophisticated and demanding.

In the PMM industry the outsourcing deals is often fail because of the disparity of expectations of the clients towards the services offered by the outsourcing service providers (Usher, 2003). This is due to both parties entering into an outsourcing agreement every so often having different goals and objectives (Jakki et al., 2011). The clients often lack of capability in measuring the total value that can be gained in outsourcing certain peripheral business functions. Moreover, the requirements of both the service provider and client are still ambiguous and there is no evidence or reliable data on the effectiveness of outsourcing in Malaysia and this may lead to the confusion and misapprehension of each other's expectation. The outcome of outsourcing is still unclear and not properly investigated in Malaysia. Hence, it is imperative to investigate the outcomes of outsourcing as the clients tend to consider the cost and benefits of every investment made (Bin Jiang \& Amer Qureshi, 2006). 
PMM is a combination of activities carried out to retain an item in, or restore it to, an acceptable condition (Paul, 2001). It is an essential activity which supports lifestyle, livelihood and maintains the considerable asset value. Due to the popularity gain on outsourcing strategy and the limited research in this field, hence, it is worth to examine the performance and implementation of the service provision in the Malaysian context. This research aims to investigate the level of outsourcing effectiveness at the perception of service providers and clients, and to examine the chasm between service providers and clients' effectiveness. This paper therefore presents the findings on perceived PMM outsourcing effectiveness between service providers and clients. Subsequently, the chasm between service providers and clients' perceptions on PMM outsourcing effectiveness will be revealed.

\subsection{LITERATURE REVIEW}

\subsection{Debates on Outsourcing}

Lei and Hitt (1995) define outsourcing as reliance on external sources for manufacturing components and other value-adding activities. Sharpe (1997) defined outsourcing as the turning over of those activities outside the organisation's chosen core competencies to a supplier or vendor. Perry (1997) in turn professes outsourcing as 'employees from another firm carrying out tasks previously performed by one's own employees'. In general, outsourcing refers to business strategy where organisation engages external party in carrying out a certain business function, more than often non-core business functions that comprise the management of activities and delivery of agreed work scope, within agreed timeframe and with agreed standard.

Outsourcing has emerged as one of the most recent management strategies to response to demands for more efficient ways to address organisational competitiveness (Bin Jiang \& Amer Qureshi, 2006; Mullin, 1996). It is also agreed by Kirti and Leena (2011) that outsourcing aims to improve clients' competitive advantage. The broadly presented definitions of outsourcing have been varied from what is concerned with the transfer of goods and services that have been carried out internally to an external provider (Domberger, 1998) in procuring the products or services from external sources of organisation (Lankford \& Parsa, 1999). To illustrate the main features of outsourcing, the transaction involved normally consists of two parts; the transfer to a third party on the responsibility for the operation and management of part of an organisation, and the provision of services to the organisation by the service provider, usually for an agreed period of time (Raja \& Kherun, 2010).

Outsourcing has evolved from being a cost cutting to a delicate strategy of alliances and joint-venture with providers in enhancing the delivery performance (Goncalo, 2005). Research done by Lankford and Parsa (1999) proved that outsourcing operations are the trend of the future, and those organisations which already adopted outsourcing are satisfied with the outcome. Presently the outsourcing of selected organisational activities in the PMM is also considered as an important element of corporate strategy (Lee, 2012). Outsourcing of services has proliferated through different industries and property services are regularly contracted out (Field Fisher Waterhouse and Remit Consulting, 2004). The stakeholders are looking for improvements to ensure productivity, efficiency and quality to the best value of services through outsourcing (Audit Commission, 2005; Choi, 1999; Farnham \& Horton, 1996; Price Waterhouse Coopers, 1999).

\subsection{Objectives of Outsourcing}

The decision to outsource certain business function of an organisation is driven by a variety of considerations (Lacity \& Hirschheim, 1993; Lacity et al., 1996; McFarlan \& Nolan, 1995). Outsourcing strategy helps organisations in improving competitive pressures, improve quality and efficiency, increase the access to functional expertise, and to elevate the potential for creating strategic business alliances and reduce internal administrative problems (Fill \& Visser, 2000). Outsourcing also allows organisations to exploit strengths within the supply market. Consequently, it is possible to conclude that such advantages could benefit not only the outsourcing client who get much better value for their money, but also the numerous service providers to be able to make profit (Raja \& Kherun, 2010).

\subsection{Obstacles of Outsourcing}

Gavin and Matherly (1997) classified the problems of outsourcing into three main aspects namely the people, the process and the technology. 'People' problems include the risk of employees' emotional or psychological stress, reduction of loyalty and loss of internal expertise. The 'process' in turn consists of two categories; incompatibilities between the service provider and the organisation, and the inability of organisations to adequately analyse their decision to outsource. In addition, conventional outsource 
contract covering quite a number of years, regardless of the fact that they have not made any future company plan beyond the current point of time (Teresko, 1992). Lastly, the 'technology' aspect refers to situation where organisation regularly embarked on outsourcing in the absence of any formal methodology or guidance (Cox \& Lonsdale, 1997). These problems are seen to be existed within outsourcing strategy planning.

\subsection{Criteria of Effectiveness Outsourcing}

Organisation that adopted outsourcing strategy for their PMM has to go through the process to establish and set criteria of effectiveness of outsource. According to Usher (2003), these drivers will be the benchmark used to examine the effectiveness of its implementations.

The Outsourcing Institute (1998) and Usher (2003) set out two different set of outsourcing effectiveness criteria namely: (i) the factors for successful outsourcing perspective and (ii) the divergent perspective. Both set of criteria will be used to assess the effectiveness.

\subsubsection{Factors for successful outsourcing perspective}

As stated in the survey of current and potential outsourcing end-users done by The Outsourcing Institute (1998), the ten most effectiveness criteria or factors for successful outsourcing comprise:

Table 1: Factors for successful outsourcing perspective - Effectiveness criteria for successful outsourcing

\begin{tabular}{|c|c|c|}
\hline No. & Effectiveness criteria & $\begin{array}{l}\text { Description } \\
\end{array}$ \\
\hline 1 & $\begin{array}{llll}\text { Understanding } & \text { company } & \text { goals } & \text { and } \\
\text { objectives }\end{array}$ & $\begin{array}{l}\text { In making the decision whether or not to outsource certain business activities } \\
\text { to external party, it involves the in-depth study and understanding on the } \\
\text { company goals and objectives. In addition, the organisation needs to possess } \\
\text { a comprehensive and well equipped knowledge on the outsourcing strategy } \\
\text { context. }\end{array}$ \\
\hline 2 & A strategic vision and plan & $\begin{array}{l}\text { With the decision made to outsource certain business activities, a strategic } \\
\text { vision and plan shall be in place to define the outsourcing strategy for each } \\
\text { business activities being outsourced. }\end{array}$ \\
\hline 3 & Selecting the right vendor & $\begin{array}{l}\text { Selecting the right vendor from different vendors that offer the same service } \\
\text { is a significant criteria of effectiveness in outsourcing. Client should } \\
\text { thoroughly screen through the vendors' company background, track record } \\
\text { and financial stability. }\end{array}$ \\
\hline 4 & On-going management of the relationships & $\begin{array}{l}\text { Even though the outsourcing client is not involve in neither the process nor } \\
\text { the management function, it is advised by The Outsourcing Institute (1998) } \\
\text { that client should maintain on-going management of the relationships with } \\
\text { their service provider. }\end{array}$ \\
\hline 5 & A properly structured contract & $\begin{array}{l}\text { Contract awarded to successful service provider shall be structured in a right } \\
\text { manner and comprehensive, and clear enough for easy understanding. A } \\
\text { properly structured contract should be attached together with a detailed service } \\
\text { level agreement (SLA), predictive maintenance schedule, work performance } \\
\text { audit framework and so on. }\end{array}$ \\
\hline 6 & $\begin{array}{l}\text { Open communication with affected } \\
\text { individual / groups }\end{array}$ & $\begin{array}{l}\text { To allow a healthy communication flow, both clients and service providers } \\
\text { shall maintain an open communication. It enable the problems to be } \\
\text { highlighted and discussed with the affected individual or groups so that } \\
\text { precautions can be raised and avoid any possible problems to exist or getting } \\
\text { worsen. }\end{array}$ \\
\hline 7 & Senior executive support and involvement & $\begin{array}{l}\text { Support and involvement from the management or senior executive of an } \\
\text { organisation that outsources certain business activities are the essential } \\
\text { elements in turning an outsourcing process to be effective. This is due to the }\end{array}$ \\
\hline
\end{tabular}




\begin{tabular}{|c|l|l|}
\hline & & $\begin{array}{l}\text { collaboration and alliance built between the parties in delivering value added } \\
\text { services. }\end{array}$ \\
\hline 8 & Careful attention to personnel issues & $\begin{array}{l}\text { Attention shall be paid on the manpower requirement at a certain period of } \\
\text { time if there is any inconsistency in terms of workload due to any factor in } \\
\text { order to achieve an optimisation of resource allocation. }\end{array}$ \\
\hline 9 & Near term financial justification & $\begin{array}{l}\text { Successful service provider being awarded with contract shall be assessed not } \\
\text { only the work performance and technical ability, but also their firm's financial } \\
\text { capability to carry on with the engagement even though the contract amount } \\
\text { is huge. The intention is to avoid abandonment of work or forced termination } \\
\text { of contract because of the financial problem faced by the service provider. }\end{array}$ \\
\hline 10 & Use of outside expertise & $\begin{array}{l}\text { Outsourcing is all about using outside expertise to accomplish certain business } \\
\text { activities of an organisation which they decided not to do it internally. The } \\
\text { decision may be due to the lack of internal skill, to achieve better result, cost } \\
\text { saving purpose, focuses on core business activities and so on. Service provider } \\
\text { shall be equipped with expected competency level and with required skill or } \\
\text { experience in handling the works. }\end{array}$ \\
\hline
\end{tabular}

\subsubsection{Divergent perspective}

Traditional outsourcing emphasis on tactical benefits like cost reduction, cheaper labour cost and was then been replaced by productivity, flexibility, innovation and access to new technologies (Dean \& Yunus, 2000; Wild et al., 1999). Subsequent to this, divergent perspective is recognised by Usher (2003) where he argues that the traditional method of evaluating the advantages and disadvantages of outsourcing can be replaced with a detailed consideration of the requirements from such an outsourcing relationship. This can help to offer a better understanding on the related issues and to establish success factors in determining whether the implementation is effective or not. The criteria of the effectiveness can be made in Table 2 below (ibid):

Table 2: Divergent perspective - Effectiveness criteria

\begin{tabular}{|c|l|l|}
\hline No. & \multicolumn{1}{|c|}{ Effectiveness criteria } & \multicolumn{1}{c|}{ Description } \\
\hline 1 & Cost & $\begin{array}{l}\text { The overall cost of the contract containing all self-performed and } \\
\text { subcontracted specialist services is one of the evaluation criteria to reveal the } \\
\text { effectiveness of outsourcing. }\end{array}$ \\
\hline 3 & Quality & $\begin{array}{l}\text { The service levels specified in SLA are usually being taken to measure or } \\
\text { determine the quality of work delivered. }\end{array}$ \\
\hline 4 & Specialisation and diversity & $\begin{array}{l}\text { This criterion refers to the extent to which effective cost of the contract may } \\
\text { differ to either party (either through unexpected price increases or base cost } \\
\text { increases to the service provider against fixed contractual sum). All types of } \\
\text { risks involve cost, and the cost involve depends on the degree to which the } \\
\text { risk is defined, understood and accounted for. }\end{array}$ \\
\hline 5 & Responsibilities and accountabilities & $\begin{array}{l}\text { It is usual for a single outsourcing contract to comprise the provision of several } \\
\text { job functions rather than full-time equivalent (FTE) roles of a specialised and } \\
\text { marginal yet essential nature. This necessitates the retention of, or access to, } \\
\text { a number of sources of such expertise and forms these criteria where the } \\
\text { capability of service provider in terms of specialisation and diversity are taken } \\
\text { into account. }\end{array}$ \\
\hline 6 & Flexibility & $\begin{array}{l}\text { This criteria is evaluated based on the complexity and clarity of specific and } \\
\text { general roles assigned to the service provider with the award of the contract. }\end{array}$ \\
\hline 7 & Innovation & $\begin{array}{l}\text { This is referring to the competency of service provider in acting and } \\
\text { responding to varying changing job needs that may happen from time to time. }\end{array}$ \\
\hline
\end{tabular}




\begin{tabular}{|c|l|l|}
\hline 8 & Investment & $\begin{array}{l}\text { Investment criteria associates to the agreed contract duration and determined } \\
\text { stability of the contractual relationship, the extent to which time and money } \\
\text { are invested for the improvement and development of the service delivery. }\end{array}$ \\
\hline 9 & Information & $\begin{array}{l}\text { This criteria emphasises on the nature, format and validity of data, qualitative } \\
\text { and quantitative, determining performance and metrics in relation to the } \\
\text { provision of the services, and the regularity and manner of presentation of this } \\
\text { information for the benefit of both client and service provider. }\end{array}$ \\
\hline 10 & Customer orientation & $\begin{array}{l}\text { This criterion refers to the extent to which the services provided by providers } \\
\text { do understand and react to the needs of the customer at all levels. This includes } \\
\text { the support of its business to its own customers, shareholders and its } \\
\text { employees. }\end{array}$ \\
\hline
\end{tabular}

\subsection{Evaluation of Criteria for Effective Outsourcing}

By comparing between the two sets of criteria for effective outsourcing discussed above, the latter appear to be more inclusive. The first set of criteria (factors for successful outsourcing perspective) is rather general and do not cover every aspect such as quality of the services provided. However, the latter set of criteria (divergent perspective) is relatively comprehensive and covers every aspect. It is properly structured and very specific as the evaluation criteria for PMM services outsourcing and exactly matched with the objective of this study.

It is considered that the analysis above is important for both the service provider and outsourcing client to understand what are the criteria that determines whether the respective outsourcing implementation or practice is effective or ineffective. It generates the potential for a more optimistic and effective outsourcing process that meets the client's satisfaction and requirements.

\subsection{METHODOLOGY}

In this study, questionnaire survey was chosen to investigate the effectiveness of PMM outsourcing practice. This is due to responses will be assembled in a standardised way and result can be identified based on solid answer and analyse statistically.

The questionnaires were adopted and modified from the PMM services outsourcing evaluation matrix by Usher (2003), as well as other information gathered and understanding gained from the literature reviews on the related topics. The questionnaire consists of two sections. Section A was to survey on respondents' demographic. Section B delves into the perception of outsourcing service providers and clients towards the criteria that determine effectiveness level of PMM outsourcing. Respondents were asked to rank the agreeable level of the criteria by circling the most appropriate answer using the Likert Scale: one (strongly disagree), two (disagree), three (unsure), four (agree) and five (strongly agree). These five point scale format is adopted as it is normally used to measure the strength of an attitude or an opinion as reported by Parmjit et al. (2006). Likert Scale indicates rank order where respondents respond to the questions or statements by circling the number where they perceive the points of the scale as appropriate (Bell \& Opie, 2002). The draft questionnaire was then sent for pilot test to ten experienced practitioners with over ten year of experience to comment on the set of questionnaire. It was then refined to be more precise, concise and easy to understand based on the general comments received.

The targeted respondents for this research were divided into two groups: the clients and the service providers. Respondents from the clients consist of property owner, property user or tenant and property management consultant. Service providers consist of the cleaning service provider, security service provider, mechanical and electrical (M\&E) maintenance vendor and landscape maintenance contractor. Respondents of each group will be answering the same questionnaire, and the feedbacks between both groups will be analysed separately in order to reveal the effectiveness gap on PMM services outsourcing practice.

A total of 100 questionnaires were distributed to the respondents in the Klang Valley area which consist of 50 sets to PMM outsourcing service providers and another 50 sets to clients group. The response rate is $59 \%$ or 59 questionnaires were answered and returned. It was the combination of 19 feedbacks from outsourcing service providers and 40 feedbacks from all varying types of outsourcing clients. 
The data obtained from the questionnaires were analysed using the quantitative approach. For this purpose, the Statistical Package for Social Science Research (SPSS) version 20.0 was used to perform the data analysis. SPSS performs descriptive statistics and inferential statistics and is widely used to analyse data (Lipsey \& Wilson, 2001; Steven et al., 2001). The result evaluated is used in the findings of the objectives in this study.

\subsection{RESULT AND ANALYSIS}

The internal consistency of the instruments was assessed through 20 items using Cronbach's Alpha. The result shows that the Alpha's coefficient was 0.913 . It can be concluded that the instrument was reliable and applicable to be used.

The mean result is presented in Table 3. The results shown in the table were ranked from the highest mean to the lowest mean difference on criteria of effective outsourcing perceived by both service providers and clients group. As shown in Table 3, the biggest gap between perceptions of both groups is 'best possible affordable/ sustainable levels' (quality) with differential of 2.01. The average mean rated by service providers for this aspect was 1.53 , compared with 3.54 of average for clients group. This may be due to the disagreement of service providers that their work qualities are not just maintained at sustainable level at all times. Instead, service providers highly agree on the other aspect of quality which is 'highest possible quality, with systems' that reflect the perception that their service cultures are to maintain highest possible quality with systematic approach. Quality creates the biggest gap as quality is a common words and difficult to define. Thus, to overcome these both service providers and clients need to define or operationalise the quality criteria that they want to achieve.

Table 3: Ranking of the gap of criteria for effective outsourcing

\begin{tabular}{|c|c|c|c|c|}
\hline Criteria & Sub-criteria & $\begin{array}{c}\text { Mean } \\
\text { (Service provider) }\end{array}$ & $\begin{array}{l}\text { Mean } \\
\text { (Client) }\end{array}$ & $\begin{array}{l}\text { Difference } \\
\text { of mean }\end{array}$ \\
\hline 1. Quality & Best possible affordable / sustainable level & 1.53 & 3.54 & 2.01 \\
\hline 2. Risk and liabilities & Accept as little risk, security of contract & 1.32 & 3.32 & 2.00 \\
\hline 3. Flexibility & Meet changes with existing resource base & 1.63 & 3.61 & 1.98 \\
\hline 4. Cost & Highest possible margins & 1.47 & 3.44 & 1.97 \\
\hline 5. Customer orientation & On the job training, existing processes & 1.74 & 3.58 & 1.84 \\
\hline 6. Quality & Highest possible quality, with systems & 4.63 & 2.97 & 1.66 \\
\hline $\begin{array}{l}\text { 7. Specialisation and } \\
\text { diversity }\end{array}$ & Maintain minimal non-fee earning overhead & 1.94 & 3.60 & 1.66 \\
\hline 8. Flexibility & Immediate reaction to changing needs & 4.58 & 2.96 & 1.62 \\
\hline 9. Cost & Lowest cost possible & 4.37 & 2.77 & 1.60 \\
\hline 10. Innovation & Initial innovation, protect intellectual capital & 1.89 & 3.47 & 1.58 \\
\hline 11. Innovation & Consistent and effective new approaches & 4.42 & 2.86 & 1.56 \\
\hline 12. Customer orientation & Systems, processes and training & 4.42 & 3.05 & 1.37 \\
\hline 13. Risk and liabilities & Transfer risk, retain contract flexibility & 4.16 & 2.87 & 1.29 \\
\hline $\begin{array}{l}\text { 14. Specialisation and } \\
\text { diversity }\end{array}$ & Call upon significant resource base & 4.00 & 2.77 & 1.23 \\
\hline 15. Information & Data analysis, bespoke reporting & 4.21 & 3.00 & 1.21 \\
\hline 16. Investment & Fund central resource, use on all accounts & 2.16 & 3.34 & 1.18 \\
\hline 17. Investment & $\begin{array}{l}\text { Resources and extra-curricular input for free } \\
\text { in exchange for long-term contract }\end{array}$ & 4.05 & 2.93 & 1.12 \\
\hline $\begin{array}{l}\text { 18. Responsibilities and } \\
\text { accountabilities }\end{array}$ & Single point of responsibility / accountability & 4.32 & 3.22 & 1.10 \\
\hline 19. Information & Existing data system, standard reporting & 2.11 & 3.20 & 1.09 \\
\hline $\begin{array}{l}\text { 20. Responsibilities and } \\
\text { accountabilities }\end{array}$ & $\begin{array}{l}\text { Shared accountability with client and/or } \\
\text { subcontractors }\end{array}$ & 2.68 & 3.50 & 0.82 \\
\hline
\end{tabular}


Secondly, the biggest gap is 'accept as little risk, security of contract' (risk and liabilities) with differential of 2.00 while 'meet changes with existing resource base' (flexibility) ranked the third biggest gap with differential of 1.98. Criteria with least gap is 'shared accountability with client and/or subcontractors' (responsibilities and accountabilities) showing the differential of 0.82 between the mean of both groups. This is followed by 'existing data system, standard reporting' (information) and 'single point of responsibility / accountability' (responsibilities and accountabilities) with differential of 1.09 and 1.10 respectively. The first research objective was achieved with the identified overall mean results of both the service providers and clients' perceptions towards outsourcing practices and implementations effectiveness. The variances between perceived effectiveness by both groups are considerably significant, which presented the disparity of perception of each group. This is due to both service providers and clients are in fact having different goals and objectives in the outsourcing strategy.

\subsection{DISCUSSION ON FINDINGS}

Respondents from the two groups basically perceive differently in terms of outsourcing effectiveness. By comparing each mean of each criteria among the service providers and clients group, it appear that the greatest variances of average mean are results derived from the former group rather than the later one. The great discrepancy of mean occurs in the service providers group are due to the reasons that they do take into account the categories of clients and their budget set, outsourcing projects and other factors. The results also depicts that service providers are prioritising the quality of service, as well as conscious about innovation of new approaches and flexibility to accommodate immediate changing needs.

Table 4: Ranking of the gap of criteria for effective outsourcing (Service providers group)

\begin{tabular}{cllc}
\hline Rank & Criteria & Sub-criteria & $\begin{array}{c}\text { Mean } \\
\text { (Service provider) }\end{array}$ \\
\hline 1 & Quality & Highest possible quality, with systems & 4.63 \\
2 & Flexibility & Immediate reaction to changing needs & 4.58 \\
3 & Innovation & Consistent and effective new approaches & 4.42 \\
4 & Customer orientation & Systems, processes and training & 4.42 \\
5 & Cost & Lowest cost possible & 4.37 \\
6 & Responsibilities and & Single point of responsibility / accountability & 4.32 \\
& accountabilities & Data analysis, bespoke reporting & 4.21 \\
7 & Information & Transfer risk, retain contract flexibility & 4.16 \\
8 & Risk and liabilities & Resources and extra-curricular input for free & 4.05 \\
9 & Investment & in exchange for long-term contract & 4.00 \\
& & Call upon significant resource base & \\
10 & Specialisation and & Shared accountability with client and/or & 2.68 \\
& diversity & subcontractors & \\
11 & Responsibilities and & Fund central resource, use on all accounts & 2.16 \\
& accountabilities & Existing data system, standard reporting & 2.11 \\
12 & Investment & Maintain minimal non-fee earning overhead & 1.94 \\
13 & Information & & \\
14 & Specialisation and & Initial innovation, protect intellectual capital & 1.89 \\
& diversity & On the job training, existing processes & 1.74 \\
15 & Innovation & Meet changes with existing resource base & 1.63 \\
16 & Customer orientation & Best possible affordable / sustainable level & 1.53 \\
17 & Flexibility & Highest possible margins & 1.47 \\
18 & Quality & Accept as little risk, security of contract & 1.32 \\
19 & Cost & & \\
20 & Risk and liabilities & &
\end{tabular}


Table 5: Ranking of the gap of criteria for effective outsourcing (Clients group)

\begin{tabular}{|c|c|c|c|}
\hline Rank & Criteria & Sub-criteria & $\begin{array}{c}\text { Mean } \\
\text { (Client) }\end{array}$ \\
\hline 1 & Flexibility & Meet changes with existing resource base & 3.61 \\
\hline 2 & $\begin{array}{l}\text { Specialisation and } \\
\text { diversity }\end{array}$ & Maintain minimal non-fee earning overhead & 3.60 \\
\hline 3 & Customer orientation & On the job training, existing processes & 3.58 \\
\hline 4 & Quality & Best possible affordable / sustainable level & 3.54 \\
\hline 5 & $\begin{array}{l}\text { Responsibilities and } \\
\text { accountabilities }\end{array}$ & $\begin{array}{l}\text { Shared accountability with client and/or } \\
\text { subcontractors }\end{array}$ & 3.50 \\
\hline 6 & Innovation & Initial innovation, protect intellectual capital & 3.47 \\
\hline 7 & Cost & Highest possible margins & 3.44 \\
\hline 8 & Investment & Fund central resource, use on all accounts & 3.34 \\
\hline 9 & Risk and liabilities & Accept as little risk, security of contract & 3.32 \\
\hline 10 & $\begin{array}{l}\text { Responsibilities and } \\
\text { accountabilities }\end{array}$ & Single point of responsibility / accountability & 3.22 \\
\hline 11 & Information & Existing data system, standard reporting & 3.20 \\
\hline 12 & Customer orientation & Systems, processes and training & 3.05 \\
\hline 13 & Information & Data analysis, bespoke reporting & 3.00 \\
\hline 14 & Quality & Highest possible quality, with systems & 2.97 \\
\hline 15 & Flexibility & Immediate reaction to changing needs & 2.96 \\
\hline 16 & Investment & $\begin{array}{l}\text { Resources and extra-curricular input for free } \\
\text { in exchange for long-term contract }\end{array}$ & 2.93 \\
\hline 17 & Risk and liabilities & Transfer risk, retain contract flexibility & 2.87 \\
\hline 18 & Innovation & Consistent and effective new approaches & 2.86 \\
\hline 19 & Cost & Lowest cost possible & 2.77 \\
\hline 20 & $\begin{array}{l}\text { Specialisation and } \\
\text { diversity }\end{array}$ & Call upon significant resource base & 2.77 \\
\hline
\end{tabular}

Table 4 and 5 tabulate the ranking of gap of criteria by both service providers and clients group. Both the perceived effectiveness of outsourcing by service providers and clients cannot be the same or tally with each other. This is because both parties are having different objectives and responsibilities in such PMM services outsourcing implementations and practices. Thus, a small gap is acceptable. From the result, it clearly shows that service providers are prioritising highest possible quality, flexibility in changing needs and innovation in terms of new approaches. Clients in turn prioritising flexibility in terms of meeting existing resource base, specialisation and diversity, as well as continuous on job training. By observing and responding on each other's concerns and priorities, an effective service quality will probably be equally experienced by both groups in this outsourcing deal.

However, it is important that in any outsourcing and services procurement to have a clear brief on the standards, needs, requirements and constraints at the beginning stage. Comprehensive SLA is a key document to make sure that the services outsourced are done in a proper manner agreeable by both parties (William \& Lee, 2002). Service provider must ensure that the work performed to be in accordance and compliance with the agreed SLA in order to achieve good service quality.

The gap between the results in terms of mean for perceived criteria of outsourcing effectiveness by service providers and clients have achieved the second research objective. Consequently this gives both the service providers and clients of PMM services outsourcing clear and direct ideas on the requirements or anticipation of each other to ensure the delivery of better quality services 


\subsection{CONCLUSION}

Alignment on the perceptions of service providers and clients in PMM services outsourcing effectiveness is critical for the achievement of successful outsourcing. The results of the mean shows that the perceptions of service providers and clients on PMM services outsourcing differ considerably and there exist a chasm on such perceptions of each party towards implementing and practicing it effectively. This also means that the outsourcing implementations and practises for PMM are yet to achieve effectiveness and the proper value of it. Such situation may post a negative impression to clients who are considering outsource as their PMM solution and possibly will lead to pulling back the decision to outsource. The rationale for conducting this research was the need for prompting the consciousness between service providers and clients on the extent of effectiveness of PMM services outsourcing implementations and practices so that the identified chasm of effectiveness can be addressed and further improved. This study has provided prove on studying and comparing the PMM outsourcing perceived effectiveness by service providers and clients. Results derived in this study will enable both groups in this PMM outsourcing deal to be alert with perception of each other and to play their part in maintaining this contractual relationship. The results of the study suggest that a tactful and swift mitigation is essential and important in closing or minimising these identified gaps in order to improve the current state of effectiveness and refine the PMM services outsourcing implementations and practices.

\subsection{RECOMMENDATIONS}

The key determinant towards successful PMM outsourcing implementation is client satisfaction. A detailed and well defined SLA is very important in promising the implementation quality matches with clients' expectations and avoid potentially contentious arguments (Ron, 2004). Both service providers and clients must also be able to appreciate the SLA content. In addition, a good communication environment is vital for each party to feels free for view exchange and problem solving. By doing so, both parties will be able to discuss openly on any problems encountered and share information and ideas to better increase the PMM outsourcing value.

\subsection{REFERENCES}

Audit Commission (2005). Value for money within housing: Supplementary guidance. London: HMSO.

Bell, J., \& Opie, C. (2002). Learning from research. Buckingham: Open University Press.

Bin Jiang., \& Amer Qureshi (2006). Research on outsourcing results: Current literature and future opportunities. Management Decision, 44(1), 44-55.

Choi, Y. C. (1999). The dynamics of public service contracting: The British experience. Bristol: The Policy Press of University of Bristol.

Cox, A., \& Lonsdale, C. (1997). Strategic outsourcing methodologies in UK companies. CBSP Working Paper, The University of Birmingham: Birmingham.

Dean, R., \& Yunus, K. (2000). The effects of global outsourcing strategies on participants' attitudes and organisational effectiveness. International Journal of Manpower, 21(2), 112-128.

Domberger, S. (1998). The contracting organisation: A strategic guide to outsourcing. Oxford: Oxford University Press Lankford.

W. M., \& Parsa, F. (1999). Outsourcing: A primer. Management Decision, 37(4), 310-6.

Farnham, D., \& Horton, S. (1996). Managing private and public organisations. In D. Farnham \& S. Horton (Eds.), Managing the new public services (pp 237-254). Basingstoke: Macmillan.

Field Fisher Waterhouse and Remit Consulting (2004). Outsourcing in the property industry: Now and in the future. Retrieved February 2011, from, www.remitconsulting.com.

Fill, C., \& Visser, E. (2000). The outsourcing dilemma: A composite approach to the make or buy Decision. Management Decision, $38,48-50$

Gavin, T. A. \& Matherly, C. M. (1997). Outsourcing: An operational auditing perspective. Managerial Auditing Journal, 12(3), 116122.

Goncalo, N. M. D. (2005). A study of the process and problems of strategic outsourcing on-going management (Unpublished Doctor of Philosophy thesis). Cranfield University: Bedford.

Jakki, J., Sanjit, S., \& Stanley, F. S. (2011). Mapping the outsourcing landscape. Journal of Business Strategy, 32(1), 42-50.

Jan, B., Adolfsson, P., \& Johansson, M. (2002). Outsourcing facilities management in the process industry: A Comparison of Sweedish and UK Patterns. Journal of Facilities Management, 1(3), 265-271.

Kirti, S., \& Leena, C. (2011). Configurations of outsourcing firms and organisational performance: A study of outsourcing industry in India. Strategic Outsourcing: International Journal, 4(2), 152-178. 
Lacity, M. C., \& Hirschheim, R. (1993). The information systems outsourcing bandwagon. Sloan Management Review, 35(1), 7387.

Lacity, M. C., Willcocks, I. P., \& Feeny, D. F. (1996). The value of selective it sourcing. Sloan Management Review, 37(3), 13-25.

Lankford, W. M., \& Parsa, F. (1999). Outsourcing: A primer. Management Decision, 37(4), 310-316.

Lee, C. S. (2012). Overview of the in-house and outsourcing strategies for property maintenance and management services. The Professional Journal of Royal Institution of Surveyors Malaysia, 47(1), 54-56.

Lei, D., \& Hitt, M. (1995). Strategic restructuring and outsourcing: The effect of mergers and acquisitions and LBOs on building firm skills and capabilities. Journal of Management, 21, 835-859.

Lipsey, M. W., \& Wilson, D. B. (2001). Practical meta-analysis. Thousand Oaks, LA: SAGE.

McFarlan, F. W., \& Nolan, R. L. (1995). How to manage an IT outsourcing alliance. Sloan Management Review, 32(2), 9-24.

Mullin, R. (1996). Managing the outsourced enterprise. Journal of Business Strategy, 17(14), 28-36.

Parmjit, S., Chan, Y. F. \& Gurnam, K. S. (2006). A comprehensive guide to writing a research proposal. Batu Caves: Venton Publishing.

Paul, W. (2001). Lee's building maintenance management. Oxford: Blackwell Science.

Perry, C. (1997). Outsourcing and union power. Journal of Labour Research, 18(4), 521-534.

Price Waterhouse Coopers (1999). The Hong Kong housing authority: A review of private sector involvement in estate management and maintenance services. Hong Kong Housing Authority, Hong Kong.

Raja, M. R. M., \& Kherun, N. A. (2010). Relationship between supply chain management and outsourcing (Research Paper). University Technology Malaysia, Malaysia.

Ron, D. (2004). Setting up and managing outsourcing contracts to deliver value and accommodate change. Journal of Corporate Real Estate, 6(4), $301-307$.

Sharpe, M. (1997). Outsourcing, organisational competitiveness, and work. Journal of Labour Research, 18(4), 535-549.

Steven, J. D., Barbara, G. T., \& Linda, S. F. (2001). SPSS for Windows workbook: To accompany Tabachnick and Fidell 'using multivariate statistics'. London: Allyn and Bacon.

Teresko, J. (1992). Outsourcing: Tie it to the right objectives. Industry Week, 24(11), 42-44.

The Outsourcing Institute (1998). Survey of current and potential outsourcing end-users. Retrieved June 2011, from, http://www.outsourcing.com/content.asp?page.01b/articles/intelligence/oi.top_ten_survey.html.

Usher, N. (2003). Outsource or in-house facilities management: The pros and cons. Journal of Facilities Management, 2(4), 351359.

Wild, J., Wild, K., \& Han, J. (1999). International business: An integrated approach. Eaglewood Cliffs, NJ: Prentice Hall.

William, L., \& Lee, W. M. (2002). Show me the money: Contracts and agents in service level agreement markets. Info, 14(1), 2436. 